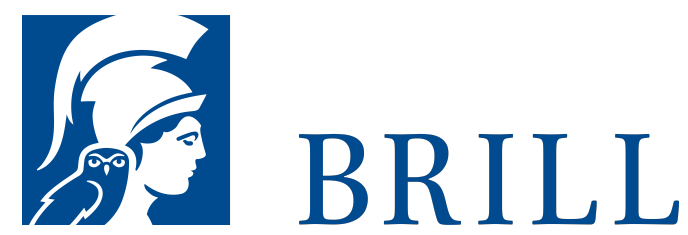

\title{
Oszillation und Kristallisation
}

Theorie und Sprache bei Novalis

Author: Franziska Struzek-Krähenbühl

Wie aus frei schwebenden Ionen und Kationen Salzgitter kristallisieren, so schlagen sich freie geistige Bewegungen in Sprache nieder, sofern nicht zielgerichtet gesprochen wird. Doch wie im Salzgitter die Elementarteilchen der Atome nicht fixiert sind, sondern nach wie vor schwingen, so ist auch die Wahrheit im Sprachkristall nicht fest und verfügbar. Novalis schwebt zwischen einer metaphysischen und einer dekonstruktiven Sprachauffassung, indem er eine dritte propagiert, die beide verbindet: die Theorie der Sprache als oszillierende Kristallisation - ein von Novalis bewusst gewähltes Paradox.

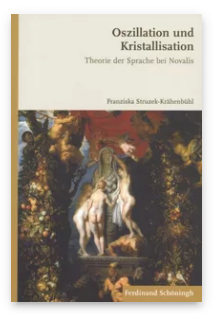

Pages: 256

Seiten

Language:

German

Subjects:

German,

Literature and

Cultural Studies

Publisher: Brill |

Schöningh

E-Book (PDF)

Released online:

$13 \mathrm{Jan} 2 \mathrm{O} 2 \mathrm{O}$

ISBN: 978-3-

657-76870-7

List price

USD \$30.00

Paperback

Publication date:

o7 Oct 2009

ISBN: 978-3-

506-76870-4

List price

USD \$30.00 
For more information see brill.com

Order information: Order online at brill.com +44330 333 0049 | customerservices@brill.com Submission information: brill.com/authors

Titles published by Brill | Fink, Brill | mentis or Brill | Schöningh: +49(o)715413279216| brill@brocom.de 